\title{
STRATEGI SISTEM REKRUTMEN DAN SELEKSI KARYAWAN PT SUMBER ALFARIA TRIJAYA TBK
}

\section{RECRUITMENT SYSTEM AND EMPLOYEE SELECTION STRATEGY PT SUMBER ALFARIA TRIJAYA TBK}

\author{
Edi Jusriadi $^{1)}$,Syafaruddin ${ }^{2}$, dan Destiani ${ }^{3)}$ \\ 1,2,3) Universitas Muhammadiyah Makassar, Sout Sulawesi, Indonesia \\ Jl. Sultan Alauddin No.259, Gn. Sari, Kec. Rappocini, Kota Makassar \\ Sulawesi Selatan 90221 \\ e-mail: edi.jusriadi@unismuh.ac.id atau edipsdm@gmail.com.
}

\begin{abstract}
ABSTRAK
Keunggulan kompetitif perusahaan sangat ditentukan oleh kualitas sumber daya manusia yang dimiliki. Sehingga dalam teori manajemen sumber daya manusia menempatkan fungsi rekrutmen dan seleksi sebagai kunci dalam mendapatkan sumber daya manusia yang memiliki keunggulan kompetitif. Sehingga penelitian ini bertujuan untuk menganalisis efektivitas pola dan sistem rekrutmen dan seleksi Karyawan Pada PT Sumber Alfaria Trijaya Tbk. Jenis dan pendekatan penelitian menggunakan pendekatan kualitatif yang fokus pada analisis pola dan sistem rekrutmen dan seleksi karyawan pada PT Sumber Alfaria Trijaya Tbk melalui analisis SWOT. Teknik pengumpulan data yang digunakan melalui wawancara dengan pimpinan, bagian personalia, dan karyawan. Hasil penelitian menunjukkan bahwa: 1) proses rekrutmen dilakukan dengan menyebar iklan melalui sosial media, website perusahaan, dan surat kabar, 2) seleksi karyawan dilakukan melalui seleksi administrasi, tes tertulis, tes wawancara, psikotes, dan tes kompetensi, dan 3) hasil analisis SWOT pada diagram cartesius menunjukkan bahwa pola dan sistem rekrutmen dan seleksi yang dilakukan PT Sumber Alfaria Trijaya Tbk berada pada kuadran I. Hal ini bermakna bahwa strategi yang harus ditetapkan dalam kodisi ini adalah mendukung kebijakan pertumbuhan yang agresif (Growth Oriented Strategy). Strategi ini menandakan keadaan perusahaan yang kuat dan mampu untuk terus berkembang dengan mengambil peluang yang ada untuk mendapatkan sumber daya manusia yang maksimal.
\end{abstract}

Kata Kunci : Rekrutmen, Seleksi Karyawan, Analisis SWOT

\begin{abstract}
A company's competitive advantage is largely determined by the quality of human resources. So that in human resource management theory, the recruitment and selection function is the key in obtaining human resources who have a competitive advantage. So this research aims to analyze the effectiveness of the patterns and systems of recruitment and selection of employees at PT Sumber Alfaria Trijaya Tbk. Types and research approaches using a qualitative approach that focuses on the analysis of patterns and systems of recruitment and selection of employees at PT Sumber Alfaria Trijaya Tbk through a SWOT analysis. Data collection techniques used through interviews with leaders, personnel, and employees. The results showed that: 1) the recruitment process was carried out by spreading advertisements through social media, company websites, and newspapers, 2) employee selection was carried out through administrative selection, written tests, interview tests, psychological tests, and competency tests, and 3) analysis results. The SWOT in the cartesius diagram shows that the recruitment and selection patterns and systems carried out by PT Sumber Alfaria Trijaya Tbk are in quadrant I. That means, the strategy must be determined in this condition is to support an aggressive growth policy (Growth Oriented Strategy). This strategy indicates, the company is strong and able to continue to grow by taking existing opportunities to obtain maximum human resources.
\end{abstract}

Keywords: Recruitment, Employee Selection, SWOT Analysis

\section{Edi Jusriadi, Syafaruddin dan Destiani}

Strategi Sistem Rekrutmen Dan Seleksi Karyawan PT Sumber Alfaria Trijaya Tbk 


\section{SEGMEN Jurnal Manajemen dan Bisnis}

Volume 17 No 1 Januari 2021

p-ISSN: 0216-938X e-ISSN: 2684-8414

\section{PENDAHULUAN}

Keunggulan kompetitif perusahaan sangat ditentukan oleh kualitas sumber daya manusia yang dimiliki. Sehingga dalam teori manajemen sumber daya manusia menempatkan fungsi rekrutmen dan seleksi sebagai kunci dalam mendapatkan sumber daya manusia yang memiliki keunggulan kompetitif (Jusriadi, 2019).Upaya yang dilakukan PT Sumber Alfaria Trijaya Tbk untuk mendapatkan karyawan yang memiliki keunggulan kompetitif melalui proses rekrutmen dan seleksi yang selektif. Proses rekrutmen yang dilakukan PT Sumber Alfaria Trijaya Tbk diawali dengan analisis jabatan untuk mendapatkan informasi aspek kuantitas dan kualitas berserta persyaratan khusus karyawan yang dibutuhkan. Rekrutmen karyawan dilakukan melalui proses pemberian informasi akan kebutuhan karyawan berserta kualifikasi dan persyaratanya yang disampaikan melalui media informasi dalam koran dan website perusahaan.Tujuan dari rekrutmen adalah untuk mengidentifikasi dan menarik para job seekers agar mau berkomitmen untuk ikut serta berpartisipasi di dalam proses rekrutmen tersebut.

Proses seleksi merupakan tahapan kedua dalam fungsi operasional manajemen sumber daya manusia. Proses seleksi dimulai pada saat seleksi administrasi, tes tertulis, tes wawancara, psikotes, tes kompetensi, dan berakhir pada pengambilan keputusan penerimaan karyawan. Dalam hal proses rekrutmen dan seleksi karyawan yang dilakukan PT Sumber Alfaria Trijaya Tbk ditemukan beberapa permasalahan yang sangat menganggu proses untuk mendapatkan karyawan yang memiliki keunggulan kompetitif diantaranya: 1) banyaknya calon pelamar yang gugur dalam seleksi administrasi karena kualifikasi yang dibutuhkan perusahaan tidak sesuai, 2) tingkat pemahaman dan kemampuan pelamar dalam menerima arahan pelaksanaan tes yang masih kurang sehingga berdampak pada rendahnya hasil tes pelamar, dan 3) masih rendahnya kemampuan intellectual capital tim seleksi sehingga masih sulit mendapatkan karyawan yang memiliki keunggulan kompetitif. Sehingga dibutuhkan pola dan analisis untuk mengevaluasi penerapan sistem rekrutmen dan seleksi yang digunakan PT Sumber Alfaria Trijaya Tbk dalam penerimaan karyawan.

\section{MANAJEMEN SUMBER DAYA MANUSIA}

Manajemen sumber daya manusia merupakan hal yang penting bagi perusahaan. Seiring perkembangan jaman, manajemen sumber daya manusia tidak hanya sebagai bagian dari perusahaan yang mengurus administrasi karyawan saja. Manajemen sumber daya manusia adalah proses memperoleh, melatihan, menilai, dan kompensasi karyawan, ikut serta dalam hubungan tenaga kerja mereka, kesehatan dan keselamatan, serta kekhawatiran terkait dengan keadilan. Tujuan keseluruhan dari manajemen sumber daya manusia adalah untuk memastikan bahwa organisasi mampu mencapai keberhasilan melalui manusia.

Manajemen sumber daya manusia pada dasarnya, kualitas organisasi sangatlah bergantung pada kualitas orang-orang yang berada didalamnya. Mendapatkan dan mempertahankan karyawan yang kompeten sangatlah penting bagi kesuksesan organisasi. Manajemen sumber daya manusia meliputi aktivitas seperti mewawancarai calon karyawan, mengorientasi karyawan baru, mengevaluasi kinerja, merancang 


\section{SEGMEN Jurnal Manajemen dan Bisnis}

Volume 17 No 1 Januari 2021

p-ISSN: 0216-938X e-ISSN: 2684-8414

program pelatihan dan kompensasi, dan lain sebagainya. Manajemen sumber daya manusia merupakan suatu proses perencanaan, pengorganisasian, pengarahan dan pengawasan kegiatan-kegiatan pengadaan, pengembangan, pemberian kompensasi, pengintegrasian, pemeliharaan dan pelepasan sumber daya manusia agar tercapai berbagai tujuan individu, organisasi dan masyarakat, (Rachmawati, 2008).

Manajemen sumber daya manusia pada hakekatnya merupakan serangkaian dari fungsi manajerial dan fungsi operasional (Stoner, 2005). Adapun fungsi-fungsi yang dimaksud adalah sebagai berikut: 1) Fungsi Manajerial berhubungan dengan fungsifungsi manajemen POAC sebagi fungsi yang dijalankan pengambil keputusan dalam suatu organisasi, 2) Fungsi Operasional berhubungan dengan fungsi teknis dalam hal perencanaan SDM, Rekrutmen, Seleksi, pemeliharaan dan pengembangan SDM

\section{SISTEM REKRUTMEN DAN SELEKSI}

\section{Rekrutmen}

Rekrutmen SDM merupakan praktik atau aktivitas yang dijalankan oleh organisasi untuk mengidentifikasi dan menarik karyawan potensial dengan strategi yang berbeda-beda, (Noe, 2010). Sedangkan (Yulianti, 2009) menyatakan bahwa rekrutmen adalah proses yang menghasilkan sejumlah pelamar yang berkualifikasi untuk pekerjaan di suatu perusahaan atau organisasi. Kesimpulan yang dapat ditarik dari penjelasan menurut para ahli yaitu, rekrutmen adalah mengidentifikasi dan mencari tenaga kerja yang kompeten.

Sistem rekrutmen karyawan pada umumnya menggunakan pendekatan sebagai beriku: 1) Merit System, yaitu penarikan karyawan didasarkan kepada kemampuan, kecakapan, keterampilan, dan pengalaman yang dimilki oleh pelamar, 2) System Patronage, yaitu sistem penarikan karyawan yang bersifat subjektif artinya didasarkan kepada adanya hubungan pribadi seperti hubungan keluarga atau relasi dengan kata lain antara pihak yang mengangkat dengan yang diangkat.

\section{Seleksi}

Seleksi adalah proses yang terdiri dari berbagai langkah yang spesifik dari kelompok pelamar yang paling cocok dan memenuhi syarat untuk jabatan tertentu, (Teguh, 2005). Proses seleksi juga merupakan upaya yang sistematis untuk mengimplementasikan rencana sumber daya manusia melalui pemilihan, evaluasi dan penyaringan atas karyawan yang memenuhi syarat. Seleksi merupakan proses pemilihan individu-individu yang memiliki kualifikasi yang relevan untuk mengisi dalam suatu organisasi (Mathis dan Jackson, 2002). Adapun langkah- langkah proses seleksi antara lain: 1) seleksi administrasi sebagai tahap awal untuk menilai kesesuian komptensi yang dimiliki pelamar dengan kebutuhan perusahaan, 2) testing yang meliputi tes tertulis, tes wawancara, psikotes, dan tes kompetensi, 3) evaluasi hasil seleksi atau pemilihan untuk menentukan lulus tidaknya pelamar dalam proses seleksi, 4) proses penyampaian informasi atau pengumuman, 5) penempatan karyawan yang dinyatakan lulus seleski, dan 6) pemeliharaan dan pengembangan karyawan melalui proses training and development.

\section{MANAJEMEN STRATEGI}

\section{Analisis SWOT}

Analisis SWOT digunakan dalam penelitian ini untuk mengevaluasi pola dan sistem rekrutmen dan seleksi yang digunakan 


\section{SEGMEN Jurnal Manajemen dan Bisnis}

Volume 17 No 1 Januari 2021

p-ISSN: 0216-938X e-ISSN: 2684-8414

PT Sumber Alfaria Trijaya Tbk dalam mendapatkan karyawan yang memiliki keunggulan kompetitif dalam bekerja. Analisis SWOT adalah identifikasi berbagai faktor secara sistematis untuk merumuskan strategi perusahaan. Analisis ini didasarkan pada logika yang dapat memaksimalkan kekuatan dan peluang, namun secara bersamaan dapat meminimalkan kelemahan dan ancaman (Rangkuti, 2009).

Proses pengambilan keputusan dengan cara ini selalu dikaitkan dengan pengembangan misi, tujuan, strategi dan kebijakan. Sehingga pada prinsipnya analisis SWOT membandingkan antara faktor eksternal (peluang dan ancaman) dan faktor internal (kekuatan dan kelemahan) guna menetapkan formulasi strategi (perencanaan strategi) dalam upaya penyusunan strategi jangka panjang. Matriks SWOT juga merupakan matching tool yang penting untuk membantu manajer mengembangkan empat tipe strategi (Purwanto, 2008). Keempat tipe strategi yang dimaksud adalah: 1) Strategi SO (Strengths Opportunities) digunakan perusahaan dengan memanfaatkan atau mengoptimalkan kekuatan (S/Strengths) yang dimiliki untuk memanfaatkan berbagai peluang (O/Opportunities), 2) Strategi WO (Weaknesses Opportunities) digunakan dengan seoptimal mungkin meminimalisir kelemahan (W/Weaknesses) yang ada untuk memanfaatkan peluang (O/Opportunities), 3) Strategi ST (Strengths Threats) digunakan dengan memanfaatkan atau mengoptimalkan kekuatan (S/Strengths) yang dimiliki guna mengurangi berbagai ancaman (T/Threats) yang mungkin melingkupi perusahaan, dan 4) Strategi WT (Weaknesses Threats) dengan mengurangi kelemahan (W/Weaknesses) untuk meminimalisir atau menghindari ancaman (T/Threats).

\section{Analisis IFAS \& EFAS}

Strategi matriks IFAS (Internal Factor Analysis Summary) merupakan rumusan analisis lingkungan internal. Matriks ini memberikan rangkuman dan evaluasi kekuatan dan kelemahan utama dalam berbagai bidang fungsional suatu unit usaha di lingkungan industrinya. Matriks IFAS juga memberikan dasar pengenalan dan evaluasi hubungan antar bidang-bidang fungsional tersebut. Internal Factor Analysis Summary (IFAS) terdiri dari: 1) Kekuatan (Strenght), analisis terhadap unsur kekuatan yang dimiliki oleh perusahaan. Misalnya saja menganalisis tentang kelebihan apa saja yang dimiliki perusahaan seperti dari segi teknologi, kualitas hasil produksi, lokasi strategis, atau unsur kekuatan lainnya yang lebih menekankan pada keunggulan perusahaan. Biasanya dalam analisis SWOT perusahaan cenderung akan membuat sebanyak mungkin daftar kekuatan sebagai upaya kompetisi, 2) Kelemahan (Weakness), Selain melihat unsur kekuatan perusahaan, sangat penting untuk mengetahui apa kelemahan yang dimiliki perusahaan. Untuk mengetahui kelemahan perusahaan bisa dengan melakukan perbandingan dengan pesaing seperti apa yang dimiliki perusahaan lain namun tidak dimiliki perusahaan Anda. Jika ingin membuat daftar kelemahan perusahaan secara lebih obyektif bisa dengan testimoni konsumen yang umumnya lebih mengetahui apa yang kurang dari sebuah perusahan.

Eksternal Factor Analysis Summary (EFAS) digunakan untuk merangkum peluang dan ancaman pada suatu unit usaha. Analisis matriks EFAS dilakukan perhitungan yang sama dengan cara menemukan matriks IFAS. Eksternal Factor Analysis Summary terdiri dari: 1) 


\section{SEGMEN Jurnal Manajemen dan Bisnis}

Volume 17 No 1 Januari 2021

p-ISSN: 0216-938X e-ISSN: 2684-8414

Peluang (Opportunity), Unsur peluang biasanya dibuat pada saat awal membangun bisnis. Ini karena bisnis dibentuk berdasarkan peluang atau kesempatan untuk menghasilkan keuntungan. Unsur peluang termasuk daftar apa saja yang memungkinkan bisnis mampu bertahan dan diterima di masyarakat, baik dalam jangka pendek maupun jangka panjang, 2) Ancaman (Threats), Analisis terhadap unsur ancaman sangat penting karena menentukan apakah bisnis dapat bertahan atau tidak di masa depan. Beberapa hal yang termasuk unsur ancaman misalnya banyaknya pesaing, ketersediaan sumber daya, jangka waktu minat konsumen, dan lain sebagainya. Membuat daftar ancaman perusahaan bisa untuk jangka pendek maupun jangka panjang serta bisa sewaktu-waktu bertambah atau berkurang.

\section{METODE PENELITIAN}

Jenis dan pendekatan penelitian menggunakan pendekatan kualitatif yang fokus pada analisis pola dan sistem rekrutmen dan seleksi karyawan pada PT Sumber Alfaria Trijaya Tbk melalui analisis SWOT. Teknik pengumpulan data yang digunakan melalui wawancara dengan pimpinan, bagian personalia, dan karyawan.

Metode analisis data yang digunakan untuk memproses hasil penelitian menggunakan analisis data model Miles dan Hubberman, dalam analisis dilakukan secara interaktif dan berlangsung secara terus menerus sampai tuntas, sehingga datanya sudah jenuh. Aktifitas analisis data yaitu, data reduction, data display, dan verification. Selanjutnya informasi yang diperoleh dimasukkan dalam matriks SWOT untuk mendapatkan kesimpulan efektivitas pola dan sistem rekrutmen dan seleksi yang dilakukan PT Sumber Alfaria Trijaya Tbk dalam penerimaan karyawan.

\section{HASIL PENELITIAN}

1. Hasil penilaian skor faktor Internal dan eksternal pada PT Sumber Alfaria Trijaya Tbk.

Hasil wawancara terhadap karyawan bagian rekrutmen dan karyawan bagian Learning and Development pada PT Sumber Alfaria Trijaya. Tbk, digunakan untuk memperoleh skor dan pembobotan faktor internal dan eksternal.

Tabel 1

Hasil Penilaian Skor Faktor Internal

\begin{tabular}{clcc}
\hline No & \multicolumn{1}{c}{ IFAS } & Skor & Bobot \\
\hline Faktor Internal (Kekuatan) & 4 & 0,17 \\
1. $\quad$ Pelamar kerja mulai usia 18 tahun & 4 & 0,15 \\
2. $\quad$ Antusias pelamar kerja & 4 & 0,17 \\
3. Mengikuti tahapan seleksi & 3 & 0,15 \\
4. $\quad$ Tepat waktu & 2 & 0,10 \\
Faktor Internal (Kelemahan) & 2 & 0,09 \\
5. Usia 17 tahun tidak diproses & 2 & 0,09 \\
6. $\quad$ Penampilan kurang menarik & 1 & 0,08 \\
7. $\quad$ Berbicara terbata-bata dan tidak ramah & $\mathbf{2 2}$ & $\mathbf{1 , 0}$ \\
8. $\quad$ Waktu Seleksi yang cukup lama & \multicolumn{3}{c}{ Total }
\end{tabular}




\section{SEGMEN Jurnal Manajemen dan Bisnis}

Volume 17 No 1 Januari 2021

p-ISSN: 0216-938X e-ISSN: 2684-8414

Tabel 2

Hasil Penilaian Skor Faktor Eksternal

\begin{tabular}{|c|c|c|c|}
\hline No & EFAS & Skor & Bobot \\
\hline \multicolumn{4}{|c|}{ Faktor Eksternal (Peluang) } \\
\hline 1. & Berkarir diusia muda & 4 & 0,15 \\
\hline 2. & Komunikasi yang baik & 3 & 0,17 \\
\hline 3. & Bertambahnya ilmu dari latihan saat seleksi & 3 & 0,17 \\
\hline & Penempatan dan jadwal sudah ditentukan & 3 & 0,15 \\
\hline \multicolumn{4}{|c|}{ Faktor Eksternal (Ancaman) } \\
\hline 5. & Banyaknya pesaing & 2 & 0,9 \\
\hline 6. & Jarak lokasi seleksi & 2 & 0,9 \\
\hline 7. & Calon karyawan yang suka lambat dalam berpikir & 2 & 0,8 \\
\hline & Calon karyawan yang terlambat akan digugurkan & 2 & 0,10 \\
\hline & Total & 21 & $\mathbf{1 , 0}$ \\
\hline
\end{tabular}

2. Matriks IFAS (Internal Faktor Analysis Summary)

Data yang diperoleh dalam Matriks IFAS ini berasal dari pengamatan langsung pada PT Sumber Alfaria Trijaya Tbk. Penilaian skor dan pembobotan diperoleh dari wawancara terhadap karyawan bagian rekrutmen dan karyawan bagian Learning and Development pada PT Sumber Alfaria Trijaya. Tbk.

Tabel 3

Matriks IFAS pada PT Sumber Alfaria Trijaya Tbk

\begin{tabular}{|c|c|c|c|c|}
\hline No & Kekuatan & Skor & Bobot & Skor*Bobot \\
\hline 1. & Pelamar kerja muai usia 18 tahun & 4 & 0,17 & 0,68 \\
\hline 2. & Antusias pelamar kerja & 4 & 0,15 & 0,6 \\
\hline 3. & Mengikuti tahapan seleksi & 4 & 0,17 & 0,68 \\
\hline 4. & Tepat waktu & 3 & 0,15 & 0,45 \\
\hline & & \multicolumn{2}{|c|}{ Total Kekuatan } & 2,41 \\
\hline NO & Kelemahan & Skor & Bobot & Skor*Bobot \\
\hline 1. & Usia 17 tahun tidak diproses & 2 & 0,10 & 0,2 \\
\hline 2. & Penampilan kurang menarik & 2 & 0,09 & 0,18 \\
\hline 3. & Berbicara terbata-bata dan tidak ramah & 2 & 0,09 & 0,18 \\
\hline \multirow[t]{3}{*}{4.} & Waktu Seleksi yang cukup lama & 1 & 0,08 & 0,08 \\
\hline & & \multicolumn{2}{|c|}{ Total Kelemahan } & 1,36 \\
\hline & TOTAL IFAS & \multicolumn{2}{|c|}{$2,41+1,36$} & 3,77 \\
\hline
\end{tabular}

Sumber: Hasil Olah Data Wawancara, 2019

Berdasarkan data diatas bahwa nilai kekuatan adalah nilai tertinggi untuk matriks IFAS dengan jumlah 3,78 dibandingkan dengan faktor kelemahan adalah 0,20, maka nilai yang dapat dijadikan dasar kebijakan adalah nilai kekuatan.

3. Matriks EFAS (Eksternal Faktor Analysis Summary)

Data yang diperoleh dalam Matriks EFAS ini berasal dari pengamatan langsung pada 


\section{SEGMEN Jurnal Manajemen dan Bisnis}

Volume 17 No 1 Januari 2021

p-ISSN: 0216-938X e-ISSN: 2684-8414

PT Sumber Alfaria Trijaya Tbk. Penilaian skor dan pembobotan diperoleh dari wawancara terhadap karyawan bagian rekrutmen dan karyawan bagian Learning and Development pada PT Sumber Alfaria Trijaya. Tbk.

\section{Tabel 4}

Matriks EFAS pada PT Sumber Alfaria Trijaya Tbk

\begin{tabular}{|c|c|c|c|c|}
\hline No & Peluang & Skor & Bobot & Skor*Bobot \\
\hline 1. & Berkarir diusia muda & 4 & 0,15 & 1,12 \\
\hline 2. & Komunikasi yang baik & 3 & 0,17 & 0,75 \\
\hline 3. & Bertambahnya ilmu dari latihan saat seleksi & 3 & 0,17 & 0,75 \\
\hline 4. & Penempatan dan jadwal sudah ditentukan & 3 & 0,15 & 0,45 \\
\hline & & & l Peluang & 3,07 \\
\hline No & Ancaman & Skor & Bobot & Skor*Bobot \\
\hline 1. & Banyaknya pesaing & 2 & 0,9 & 0,4 \\
\hline 2. & Jarak lokasi seleksi & 2 & 0,9 & 0,44 \\
\hline & $\begin{array}{l}\text { Calon karyawan yang suka lambat dalam } \\
\text { berpikir }\end{array}$ & 2 & 0,8 & 0,4 \\
\hline 4. & $\begin{array}{l}\text { Calon karyawan yang terlambat akan } \\
\text { digugurkan }\end{array}$ & 2 & 0,10 & 0,44 \\
\hline \multicolumn{4}{|c|}{ Total Ancaman } & $\mathbf{0 , 9 6}$ \\
\hline \multicolumn{2}{|r|}{ TOTAL EFAS } & \multicolumn{2}{|c|}{$\mathbf{3 , 0 7}+\mathbf{0 , 9 6}$} & 4,03 \\
\hline
\end{tabular}

Berdasarkan data diatas bahwa nilai peluang adalah nilai tertinggi untuk Matriks EFAS dengan jumlah 3,07 dibandingkan dengan faktor Ancaman adalah 0,96, maka nilai yang dapat dijadikan dasar kebijakan adalah nilai peluang.

\section{Diagram Cartesius Analisis SWOT}

Hasil dari analisis IFAS, faktor kekuatan dan kelemahan memiliki total skor 3,77 yang berarti bahwa PT Sumber Alfaria Trijaya Tbk berada pada titik rata-rata dalam usahanya menjalankan strategi memanfaatkan kekuatan untuk mengatasi kelemahan. Sedangkan hasil dari analisis EFAS, faktor peluang dan ancaman memiliki total skor 4,03 yang berarti bahwa PT Sumber Alfaria Trijaya Tbk berada pada titik rata-rata dalam usahanya menjalankan strategi memanfaatkan peluang dan menghindari ancaman.

Selanjutnya nilai total skor dari masing-masing faktor dapat dirinci kekuatan 2,41, kelemahan 1,36, peluang 3,07, ancaman 0,96. Maka diketahui selisih total skor faktor kekuatan dan kelemahan adalah (+) 1,05, sedangkan selisih total skor faktor peluang dan ancaman adalah (+) 2,11. Pada gambar 1, menjelaskan diagram Cartesius Analisis SWOT.

Gambar 1 adalah Diagram Cartesius menunjukkan bahwa PT Sumber Alfaria Trijaya Tbk berada pada kuadran growth dimana kuadran tersebut merupakan situasi yang sangat menguntungkan. Perusahaan tersebut memiliki peluang dan kekuatan sehingga dapat memanfaatkan peluang yang ada. 


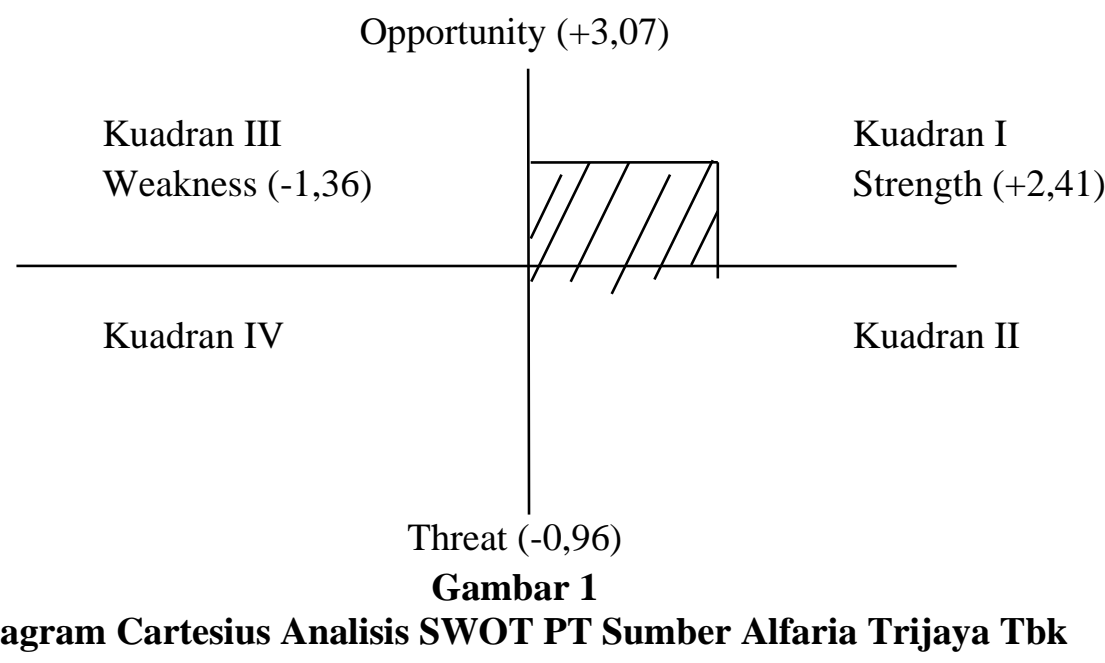

Strategi yang harus ditetapkan dalam kodisi ini adalah mendukung kebijakan pertumbuhan yang agresif (Growth Oriented Strategy). Strategi ini menandakan keadaan perusahaan yang kuat dan mampu untuk terus berkembang dengan mengambil peluang yang ada untuk mendapatkan sumber daya manusia yang maksimal. Untuk mendukung Growth Oriented Strategy maka PT Sumber Alfaria Trijaya Tbk harus mampu memaksimalkan sumber daya perusahaan yang dimiliki baik yang bersifat tangible resource maupun yang bersifat intangible resource, (Jusriadi,2018)

Hambatan yang terjadi dalam perekrutan kadangkala banyak kandidat yang tidak sesuai dengan standar kualifikasi yang diterapkan oleh perusahaan. Adapun hambatan dalam proses seleksi karyawan lebih kepada kemampuan masing-masing individu dalam menerima arahan tes, hal ini dikarenakan banyaknya pelamar yang kurang memiliki keahlian atau keterampilan, pengalaman kerja maupun pengetahuan.

Hasil penelitian ini sejalan dengan hasil penelitian (Naibaho, 2012), menemukan bahwa pola dan sistem rekrutmen dan seleksi karyawan yang baik akan berpengaruh kepada daya saing perusahaan. Dalam hal informasi proses perekrutan karyawan yang terjadi di PT Sumber Alfaria Trijaya Tbk melalui media internet, media massa seperti koran dan referensi karyawan yang ada di perusahaan hasil penelitian ini sejalan dengan hasil penelitian (Halim, 2016), yang menemukan bahwa media informasi paling efektif untuk menyampaikan informasi pekerjaan melalui media internet, media massa atau referensi teman. Sedangkan dari aspek seleksi yang dilakukan PT Sumber Alfaria Trijaya Tbk melalui tahapan seleksi administrasi, tes tertulis, tes wawancara, psikotes, dan tes kompetensi. Hasil penelitian ini sejalan dengan temuan penelitian (Rohmatin, 2016; Pusparan, 2018), bahwa untuk mendapatkan karyawan yang memiliki daya saing tinggi maka diperlukan pola dan sistem yang baik dan dilaksanakan secara jujur sesuai tahapan yang ditetapkan.

\section{DAFTAR PUSTAKA}

Fadyanto., Hendra. 2017, Analisis Sistem

Rekrutmen dan Seleksi pada Pt. X. Jurnal Angora, (Online), Vol.5, No.1, 


\section{SEGMEN Jurnal Manajemen dan Bisnis}

Volume 17 No 1 Januari 2021

p-ISSN: 0216-938X e-ISSN: 2684-8414

https://media.neliti.com/media/publicatio ns/56551-ID-analisis-sistem-rekrutmendan-seleksi-pa.pdf, diakses 15 April 2019)

Halim, William Santosa. 2016, Analisis Rekrutmen dan Seleksi Karyawan pada Perusahaan Bihun Cahaya Tiga Tunggal. Jurnal Angora, (Online), Vol.4, No.1, https://media.neliti.com/media/publicatio ns/36478-ID-analisis rekrutmen-dan seleksi karyawan-pada-perusahaanbihun-cahaya-tiga-tungga.pdf, diakses pada 15 April 2019).

Jusriadi, Edi dan Rahim, Rahman, 2019. Human Capital Development. Pekalongan : NEM

Jusriadi, E., Rusydi, M., \& Muttalib, A. (2018). Konstruksi Dimensi Intellectual Capital dalam Mendukung Kinerja Dosen Perguruan Tinggi Muhammadiyah di Sulawesi Selatan. Balance, 15(02). http://journal.um-

surabaya.ac.id/index.php/balance/article/ view/1781.

Jusriadi, E., \& Akib, M. (2018). Model Pengembangan Sumber Daya Manusia Bagian Produksi pada PT. Frisian Flag Cabang Makassar. Profitability: Jurnal Ilmu Manajemen,2(1),38-49. https://journal.unismuh.ac.id/index.php/p rofitability/article/view/1957

Mathis, dan Jackson. 2002. Manajemen Sumber Daya Manusia, edisi pertama, Cetakan pertama,Yogyakarta : Salemba Empat

Naibaho, Hastuti. 2012. Analisis Pengaruh Rekrutmen dan Seleksi Terhadap Kinerja Karyawan di Indonesia : Sebuah Studi Terhadap Literatur. Jurnal
Eksekutif,(Online),Vol.9.http://jurnal.ib mt.ac.id/index.php/jeksekutif/article/dow nload/27/26, diakses 15 April 2019).

Noe R. 2010. Manajemen Sumber Daya Manusia. Jakarta : Salemba Empat

Purwanto. $2008 . \quad$ Manajemen Strategi.Bandung : Yrama Widya

Pusparani, Devira, 2018. Analisis Proses Pelaksanaan Rekrutmen, Seleksi, dan Penempatan Kerja Karyawan (Studi pada Hotel dan Restoran Mahkota Plengkung Bayuwangi). Jurnal Administrasi Bisnis, (Online), Vol.58,No.2. http://administrasibisnis.studentjournal.u b.ac.id/index.php/jab/article/download/2 436/2832, diakses 15 April 2019).

Rohmatin, Nur, 2016. Analisis Pola Rekrutmen dan Seleksi Karyawan di BRI Syariah. Jurnal Nisbah, (Online), Vol.2, No.1.

https://ojs.unida.ac.id/JN/article/downloa d/249/60, diakses 15 April 2019).

Rachmawati Ike Kusdyah. 2008. Manajemen Sumber Daya Manusia, Edisi Pertama.Jakarta: Andi Offset.

Rangkuty, F. 2009. Analisis SWOT Cara Perhitungan Bobot, Rating, dan OCAI.Jakarta: PT.Gramedia Pustaka Utama.

Teguh, Ambar. 2005. Manajemen Sumber Daya Manusia, Cet I. Jakarta: Graha Ilmu. 